To the Editors:

\title{
Shift in the transmission pattern of dengue serotypes and concurrent infection with more than one dengue virus serotype
}

\author{
Ceylon Medical Journal 2011; 56: 176-178
}

Sri Lanka experienced an outbreak of dengue in 2009 with the number of hospitalised cases reaching epidemic proportions. Previous outbreaks experienced in 1989 and 2000 have been attributed to the emergence of new clades of DEN-3 (dengue virus serotype 3[1].

All four serotypes of dengue have been cotransmitting in the country for many years [2]. However, they do not occur in equal abundance. In a series of 477 dengue tests done in Colombo in 2007, among 55 positive detections, the serotypes detected were DEN-1 in $1(1.8 \%)$; DEN-2 (dengue virus serotype 2 ) in $25(40.0 \%$ ), and DEN3 in 19 (34.5\%). DEN-4 (dengue virus serotype 4 ) was not detected. The serotype could not be determined in 9 $(16.3 \%)$ [3]. It is well known that shifts in the relative abundance of serotypes could result in dengue outbreaks.

There is however, no systematic surveillance to detect shifts in the transmission pattern of dengue serotypes in Sri Lanka. We have been performing dengue testing since January 2006. We performed dengue molecular serotyping on samples in which the dengue virus was detected. The samples sent for testing were from patients with fever. It is not known whether a diagnosis of dengue fever had been made in these patients, at what day of fever the samples

were collected, or what the clinical outcomes were. Since our laboratory is a free standing laboratory we do not have access to the clinical records of the patients to correlate the clinical picture with our results. Although our data is not representative of the entire country it appears to be one of the sources of data available on the molecular serotypes prevalent in Sri Lanka during this outbreak.

Testing for dengue was performed as follows: viral RNA was extracted from serum using the NucleoSpin ${ }^{\circledR}$ nucleic acid purification kit (Macherey Nagel, Germany) according to the manufacturer's protocol. Primers described by Lanciotti and colleagues were employed to detect the $\mathrm{C}$ and PrM genes of the dengue virus [4]. Thereafter Reverse transcriptase (RT)-PCR was carried out. Briefly, $10 \mu$ l of the extracted viral RNA was mixed with $100 \mu \mathrm{M}$ Random Hexamer primer at $70^{\circ} \mathrm{C}$ for 5 minutes. Then $7 \mu$ of RT mix containing $5 x$ Reaction Buffer $[250 \mathrm{mM}$ Tris$\mathrm{HCl}\left(\mathrm{PH} 8.3\right.$ at $\left.25^{\circ} \mathrm{C}\right), 250 \mathrm{mM} \mathrm{KCl}, 20 \mathrm{mM} \mathrm{MgCl}_{2}, 50 \mathrm{mM}$ DTT] (Fermentas, USA), $10 \mathrm{mM}$ of dNTP (Promega, USA), 40U RNase inhibitor (Fermentas, USA) were added into the mixture and incubated at $25^{\circ} \mathrm{C}$ for 5 minutes. $40 \mathrm{U}$ of MMLV Reverse transcriptase enzyme (Fermentas, USA) was then added and incubated at $37^{\circ} \mathrm{C}$ for 60 minutes for 
the reverse transcription reaction and then heated to $70^{\circ} \mathrm{C}$ for 10 minutes to inactivate the reverse transcription [4]. Thereafter PCR was carried out by adding $3 \mu$ of the cDNA to $22 \mu$ l of PCR mix consisting of $5 X$ Colorless GoTaq ${ }^{\circledR}$ Flexi Buffer [100 mM Tris- $\mathrm{HCl}\left(\mathrm{PH} 8.3\right.$ at $\left.25^{\circ} \mathrm{C}\right), 500 \mathrm{mM} \mathrm{KCl}$ ] (Promega, USA), $25 \mathrm{mM}$ of $\mathrm{MgCl}_{2}$ (Promega, USA), $2.5 \mathrm{U}$ of Taq polymerase (Promega, USA), 2 mM of dNTP(Promega, USA) and $1 \mu \mathrm{M}$ of each primer D1 and D2 [4]. After amplification of an initial step of denaturation at $94^{\circ} \mathrm{C}$ for 2 min for 1 cycle followed by 40 cycles of 30 s at $94^{\circ} \mathrm{C}$, annealing at $55^{\circ} \mathrm{C}$ for $1 \mathrm{~min}$ and extension at $72^{\circ} \mathrm{C}$ for $2 \mathrm{~min}$, with a final extension step at $72^{\circ} \mathrm{C}$ for $10 \mathrm{~min}$, the amplicons were resolved by $2 \%$ agarose gel electrophoresis. Molecular serotyping of the sample was then done by a second round amplification of the RT-PCR product with already published virus serotype specific primers [4].

Table 1. The number of cases of different Dengue serotypes detected every month from 1 January 2008 to 31 December 2009

\begin{tabular}{|c|c|c|c|c|c|c|c|c|}
\hline \multirow[t]{2}{*}{ Year } & \multirow[t]{2}{*}{ Month } & \multirow{2}{*}{$\begin{array}{c}\text { No of } \\
\text { Samples }\end{array}$} & \multirow{2}{*}{$\begin{array}{c}\text { No of } \\
\text { Positive } \\
\text { Samples }\end{array}$} & \multicolumn{4}{|c|}{ Molecular Serotype } & \multirow{2}{*}{$\begin{array}{c}\text { No of } \\
\text { DEN-1\& } \\
\text { Samples }\end{array}$} \\
\hline & & & & $D E N-1$ & $D E N-2$ & $D E N-3$ & DEN-4 & \\
\hline \multirow[t]{14}{*}{2008} & January & 10 & 5 & 0 & 1 & 0 & 0 & 0 \\
\hline & February & 6 & 1 & 0 & 1 & 0 & 0 & 0 \\
\hline & March & 6 & 0 & 0 & 0 & 0 & 0 & 0 \\
\hline & April & 23 & 8 & 0 & 4 & 4 & 0 & 0 \\
\hline & May & 28 & 1 & 0 & 0 & 1 & 0 & 0 \\
\hline & June & 38 & 5 & 0 & 3 & 1 & 0 & 0 \\
\hline & July & 24 & 2 & 0 & 0 & 1 & 0 & 0 \\
\hline & August & 10 & 1 & 0 & 0 & 1 & 0 & 0 \\
\hline & September & 6 & 1 & 0 & 0 & 1 & 0 & 0 \\
\hline & October & 4 & 0 & 0 & 0 & 0 & 0 & 0 \\
\hline & November & 3 & 1 & 0 & 1 & 0 & 0 & 0 \\
\hline & December & 5 & 1 & 0 & 1 & 0 & 0 & 0 \\
\hline & 2008 Total & 163 & 26 & 0 & 11 & 9 & 0 & \\
\hline & & & $16 \%$ & $0 \%$ & $42 \%$ & $35 \%$ & $0 \%$ & \\
\hline \multirow[t]{16}{*}{2009} & January & 7 & 2 & 0 & 0 & 2 & 0 & 0 \\
\hline & February & 5 & 0 & 0 & 0 & 0 & 0 & 0 \\
\hline & March & 13 & 1 & 0 & 0 & 1 & 0 & 0 \\
\hline & April & 6 & 1 & 1 & 0 & 0 & 0 & 0 \\
\hline & May & 29 & 7 & 4 & 3 & 2 & 0 & 2 \\
\hline & June & 78 & 17 & 11 & 3 & 6 & 0 & 5 \\
\hline & July & 30 & 6 & 2 & 1 & 3 & 0 & 1 \\
\hline & August & 14 & 2 & 1 & 0 & 0 & 0 & 0 \\
\hline & September & 7 & 3 & 0 & 1 & 0 & 0 & 0 \\
\hline & October & 9 & 0 & 0 & 0 & 0 & 0 & 0 \\
\hline & November & 6 & 0 & 0 & 0 & 0 & 0 & 0 \\
\hline & December & 26 & 17 & 1 & 1 & 5 & 0 & 1 \\
\hline & 2009 Total & 230 & 56 & 20 & 9 & 19 & 0 & 9 \\
\hline & & & $24 \%$ & $36 \%$ & $16 \%$ & $34 \%$ & $0 \%$ & \\
\hline & Grand Total & 393 & 82 & 20 & 20 & 28 & 0 & 9 \\
\hline & & & $21 \%$ & $34 \%$ & $34 \%$ & $47 \%$ & $0 \%$ & \\
\hline
\end{tabular}


From 1 January 2008 to 31 December 2009 we tested a total of 393 samples - 163 in 2008 and 230 in 2009. Of them $82(21 \%)$ samples were positive for the dengue virus. We have mentioned above the limitations in access we have to the clinical data. As such it was not possible for us to pinpoint the reasons for the low detection rate in this series. One can only speculate that this may be because of sampling being done at inappropriate times or because the patients with fever did not have dengue in the first place. The latter possibility was very likely because this was a biased sample, i.e. only those who could pay for testing were tested, and because in the chaos created during the epidemic the clinicians would have been inclined to err on the side of testing than not, especially when it came to affluent patients who could afford testing.

59 of the positive sample, were successfully molecular serotyped. DEN-1, DEN-2 and DEN-3 were found in 20 (34\%), 20 (34\%) and 28 (47\%) of these 59 samples. DEN-4 was not found in any of the samples. nine $(15 \%)$ had concurrent infection with DEN-1 and DEN-3. An alternate explanation for the presence of concurrent infection is cross contamination. To completely eliminate this possibility a real time protocol with continuously sealed tubes would have been more appropriate. This was not possible however, within the financial constraints in a developing world setting. In its place stringent laboratory procedures were followed to prevent the possibility of cross contamination. This stringency of the laboratory procedures employed to prevent cross contamination was evidenced by the fact that concurrent infection with other combinations of serotypes was not detected.

Since we began surveillance in January 2008 up to 11 April 2009 only DEN-2 and DEN-3 were detected. Thereafter DEN-1 was also detected. In fact by the first week of June 2009 DEN-1 was turning out to be the predominant type detected. The pattern of dengue virus types seen in our laboratory is in Table 1. The appearance of DEN-1 and detection of mixed infection with DEN-1 and DEN-3 coincided with the peak of the outbreak in mid 2009. Although concurrent infection with more than one serotype of dengue virus in the same individual has been rarely documented, in an outbreak in 2006 in India, concurrent infection with more than one dengue serotype was reported in 19\% of the samples tested (9 out of 48) [5].

Although our data are limited, this is one source of data in the country that can provide an explanation for this dengue outbreak. We conclude therefore that a shift in the relative abundance of the DEN-1 dengue virus serotypes has contributed to this dengue outbreak in Sri Lanka as most people would not have had prior immunity to DEN-1 and that co-infection with DEN-1 and DEN-3 was an additional feature during this outbreak.

We recommend that a more systematic approach be adopted in Sri Lanka to gather dengue virus serotype data to facilitate prediction of such outbreaks in the future in advance.

\section{References}

1. Kanakaratne N, Wahala WM, Messer WB, et al. Severe dengue epidemics in Sri Lanka, 2003-2006. Emerging Infectious Diseases 2009; 15: 192-9.

2. Messer WB, Vitarana UT, Sivananthan K, et al. Epidemiology of dengue in Sri Lanka before and after the emergence of epidemic dengue hemorrhagic fever. American Journal of Tropical Medicine and Hygiene 2002; 66: 765-73.

3. Ministry of Health Care and Nutrition. Laboratory surveillance of dengue fever. Weekly Epidemiological Report 2008; 35: 3.

4. Lanciotti RS, Calisher CH, Gubler DJ, Chang GJ, Vorndam AV. Rapid detection and typing of dengue viruses from clinical samples by using reverse transcriptase-polymerase chain reaction. Journal of Clinical Microbiology 1992; 30: 545-51.

5. Bharaj P, Chahar HS, Pandey A, et al. Concurrent infections by all four dengue virus serotypes during an outbreak of dengue in 2006 in Delhi, India. Virology Journal 2008; 9: 5.

\author{
V H W Dissanayake ${ }^{1,2}$, N D Gunawardena ${ }^{1}$, N C A Gunasekara ${ }^{1}$, D R S Siriwardhana ${ }^{1}$, N Senarath ${ }^{1}$ \\ ${ }^{1}$ Asiri Centre for Genomic Medicine, Asiri Surgical Hospital, Colombo, Sri Lanka, ${ }^{2}$ Human Genetics Unit, University \\ of Colombo, Colombo, Sri Lanka.
}

Correspondence: VHWD, e-mail: <vajirahwd@hotmail.com>. Received 25 March and revised version accepted 3 September 2011. Competing interests: none declared. 